\title{
PENGARUH JUMLAH NILAI EKSPOR DAN TINGKAT INFLASI TERHADAP KURS RUPIAH TAHUN 2009-2016
}

\author{
Zumrotudz Dzakiyah \\ Universitas Jember \\ E-mail: dzakiaurora@gmail.com \\ Zarah Puspitaningtyas \\ Universitas Jember \\ E-mail: zarah@unej.ac.id \\ Yeni Puspita \\ Universitas Jember \\ E-mail: puspita yeni@yahoo.com
}

\begin{abstract}
Exchange rate is one of the elements considered by the state with an open economy system. Because the country with such a system that conducts International trade. The stability of the country's economy can also be seen from the stability of the country's exchange rate. The rupiah exchange rate in 2009 experienced a very high appreciation, but did not last long so that the fluctuation of the exchange rate continued to occur until 2016. This study aims to analyze the factors that influence the instability of the rupiah exchange rate. Export value and inflation rate are the factors that influence fluctuation of rupiah exchange rate. So the purpose in this study is to determine whether the value of exports and the rate of inflation affect the rupiah exchange rate in 2009-2016. This type of research uses a quantitative approach. Data analysis method used is regression with Error Correction Model (ECM). The results showed that the partial test of the inflation rate significantly influences the rupiah exchange rate while the export value has no significant effect on the rupiah exchange rate. In addition, the results of silmutan test show that the rate of inflation and export value affect the rupiah exchange rate.
\end{abstract}

Keywords: export value, inflation rate and rupiah exchange rate.

Abstrak

Nilai tukar adalah salah satu elemen yang dipertimbangkan oleh negara dengan sistem ekonomi terbuka. Karena negara dengan sistem seperti itu yang melakukan perdagangan Internasional. Stabilitas ekonomi negara juga dapat dilihat dari stabilitas nilai tukar negara. Nilai tukar rupiah pada tahun 2009 mengalami apresiasi yang sangat tinggi, tetapi tidak berlangsung lama sehingga fluktuasi nilai tukar terus terjadi sampai tahun 2016. Penelitian ini bertujuan untuk menganalisis faktor-faktor yang mempengaruhi ketidakstabilan nilai tukar rupiah. Nilai ekspor dan tingkat inflasi merupakan faktor-faktor yang mempengaruhi fluktuasi nilai tukar rupiah. Jadi tujuan dalam penelitian ini adalah untuk mengetahui apakah nilai ekspor dan tingkat inflasi mempengaruhi nilai tukar rupiah pada tahun 2009-2016. Jenis penelitian ini menggunakan pendekatan kuantitatif. Metode analisis data yang digunakan adalah regresi 
dengan Error Correction Model (ECM). Hasil penelitian menunjukkan bahwa uji parsial laju inflasi berpengaruh signifikan terhadap nilai tukar rupiah sedangkan nilai ekspor tidak berpengaruh signifikan terhadap nilai tukar rupiah. Selain itu, hasil uji silmutan menunjukkan bahwa tingkat inflasi dan nilai ekspor mempengaruhi nilai tukar rupiah

Kata kunci: Nilai Ekspor, Tingkat Inflasi Dan Nilai Tukar Rupiah

\section{PENDAHULUAN}

Perkembangan perekonomian dunia menuntut suatu negara untuk memperluas jaringan pasarnya melalui perdagangan internasional. Transaksi dalam perdagangan internasional yang menggunakan jenis mata uang berbeda, menjadikan kurs sebagai alat ukur dalam transaksi. Kurs merupakan mata uang asing yang menunjukkan harga atau nilai mata uang suatu negara yang dinyatakan dalam nilai mata uang negara lain (Sukirno, 2012:293). Fluktuasi kurs yang tidak stabil menunjukkan bahwa keadaan ekonomi suatu negara juga tidak stabil. Fluktuasi kurs rupiah yang mengalami depresiasi hingga apresiasi yang sangat signifikan setelah krisis moneter. Depresiasi kurs rupiah yang sangat tinggi terjadi pada tahun 2009 , pada point 8.000 ke point 12.345 . Tahun selanjutnya kurs rupiah terus mengalami fluktuasi dan depresiasi secara berkala hingga stabil pada point 9.000 pada akhir tahun 2009 hingga tahun 2012. Tahun 2012 merupakan awal kurs rupiah mengalami depresiasi bertahap hingga menyentuh point 14.000 pada tahun 2015 . Kurs rupiah dapat stabil kembali pada point 13.000-an pada tahun 2016.

Ada banyak faktor yang mempengaruhi fluktuasi kurs, Sukirno (2012:402-403) menyebutkan faktor-faktor yang mempengaruhi kurs diantaranya ekspor dan impor serta inflasi. Hasil penelitian Haryadi (2014:1) dan Syahtria, dkk (2016:59) menyatakan bahwa inflasi berpengaruh signifikan terhadap kurs. Inflasi juga menjadi alat dalam mengendalikan fluktuasi kurs melalui kebijakan moneter. Faktor lain yang mempengaruhi fluktuasi kurs adalah ekspor, ekspor merupakan kegiatan pengiriman dan penjualan barang maupun jasa ke luar negeri. Berdasarkan hasil penelitian Hazizah, dkk (2017:10-11) menyatakan bahwa ekspor tidak berpengaruh terhadap kurs rupiah, bertolak belakang dengan hasil penelitian Sedyaningrum, dkk (2016:114) yang menyatakan bahwa ekspor neto berpengaruh terhadap kurs.

Berdasarkan latar belakang yang telah diungkapkan dalam latar belakang maka peneliti merumuskan masalah penelitian "Apakah nilai ekspor dan tingkat inflasi berpengaruh terhadap kurs rupiah tahun 2009-2016?". Tujuan yang hendak dicapai dalam penelitian ini adalah "menganalisis pengaruh nilai ekspor dan tingkat inflasi terhadap kurs rupiah tahun 2009-2016". Manfaat dari penelitian ini dapat menambah kajian dan referensi mengenai faktor-faktor yang mempengaruhi fluktuasi kurs rupiah.

\section{METODE PENELITIAN}

Jenis penelitian yang digunakan dalam penelitian ini adalah analisis data sekunder dengan pendekatan kuantitatif. Data yang digunakan dalam penelitian ini berupa data sekunder dengan jenis data runtut waktu (time series) triwulan dimulai dari 2009Q.12016Q.4. Data tersebut bersumber dari publikasi laman resmi dari Bank Indonesia (BI) dan Badan Pusat Statistik (BPS). Populasi dalam penelitian ini adalah data nilai ekspor, tingkat inflasi dan kurs rupiah periode 2009Q.1-2016Q.4 sebanyak 32 data. Teknik pengambilan 
sampel menggunakan sampel jenuh, artinya semua populasi diambil peneliti sebagai sampel. Sehingga diperoleh sebanyak 32 sampel tiap variabel-variabel dalam penelitian ini.

Variabel dalam penelitian ini sebanyak tiga variabel diantaranya: kurs rupiah sebagai variabel terikat $(Y)$, variabel nilai ekspor (X1) dan tingkat inflasi $(X 2)$ sebagai variabel bebas. Variabel kurs rupiah yang digunakan merupakan perbandingan antara Rupiah Indonesia dengan Dolar Amerika. Variabel nilai ekspor berupa jumlah ekspor dalam bentuk Dolar Amerika, sedangkan variabel tingkat inflasi berupa persentase. Selanjutnya, data yang didapatkan dianalisis untuk membuktikan hipotesis. Teknik analisis yang digunakan peneliti dalam penelitian ini menggunakan regresi dengan pendekatan koreksi kesalahan atau ECM (Error Correction Model) melalui bantuan EViews 9,5 SV.

ECM dipilih oleh peneliti karena sifat data yang berupa data runtut waktu dan memiliki trend/keseimbangan saat mengalami fluktuasi. ECM menurut Basuki dan Nano (2016:201-223) dimulai dengan uji stationeritas, uji derajat kointegrasi, uji kointegrasi dan terakhir uji ECM, selanjutnya untuk melihat ketepatan model digunakan uji asumsi klasik meliputi uji multikolonieritas, uji autokorelasi, uji heteroskedasititas dan uji normalitas sedangkan uji hipotesis melalui uji $\mathrm{F}$ dan uji t.

\section{Uji Stationer}

Uji stationeritas dilakukan melalui uji unit root, uji tersebut dikembangkan oleh Dickey-Fuller (uji Augmented Dickey-Fuller) dan lebih dikenal dengan uji DF-ADF. Uji unit root ini membandingka nilai DF dan ADF berdasarkan nilai kritisnya. Variabel dikatakan stationer apabila nilai DF dan ADF lebih besar dari nilai kritis. Ketika variabel belum stationer pada tingkat level maka harus dilanjutkan uji derajat kointegrasi.

\section{Uji Derajat Kointegrasi}

Uji derajat kointegrasi sama dengan uji stationer yang membedakan keduanya terletak pada derajat first diffence atau second difference. Hail uji derajat kointegrasi juga digunakan untuk melihat variabel memiliki kointegrasi yang selanjutnya menjelaskan hubungan antara variabel dalam penelitian dan pertimbangan untuk melanjutkan uji kointegrasi. Sebelum dilanjutkan uji kointegrasi maka variabel harud lolos pada uji ini.

\section{Uji Kointegrasi}

Setelah diketahui hasil uji derajat kointegrasi maka selanjutnya dilakukan uji kointegrasi. Uji kointegrasi dilakukan dengan menggunakan uji Johansen. Uji johansen dipilih karena hasil yang ditunjukan lebih akurat dan lebih meyakinkan. Uji ini membandingkan nilai trace statistic dengan nilai kritis tingkat 5 persen atau 1 persen. Apabila variabel-variabel berkointegrasi maka dapat dilanjutkan uji ECM.

\section{Uji ECM}

Uji ECM memiliki ciri khas dengan memasukan unsur Error Correction Term (ECT) dalam model. Nilai ECT dalam penelitian ini didapatkan dengan menganut cara yang dikembangkan oleh Domowitz dan Elbadawi sehingga didapatkan persamaan rumus ECM sebagai berikut:

$$
\begin{aligned}
& \Delta U K R \_t=a \_0+a \_(1) \Delta I N F \_t+a \_(2) \llbracket \Delta E K \rrbracket \_t++a_{-} 4 e_{-}(t-1)+e_{-} t \\
& \text { Keterangan: } \\
& \triangle \mathrm{UKR} \_\mathrm{t}=\text { UKR_t- UKR_(t-1) } \\
& \Delta \mathrm{INF} \_\mathrm{t}=\mathrm{INF} \mathrm{t}-\mathrm{INF}_{-}(\mathrm{t}-1) \\
& \Delta E K \_t \quad=E K \_t-E K \_(t-1)
\end{aligned}
$$




$$
\begin{array}{ll}
\text { e_t } & =\text { residu } \\
\text { ECT } & =\left(\text { log_INF }+\log _{\text {EEK }}\right)-\log \text { _UKR } \\
\mathrm{t} & =\text { periode waktu } \\
\mathrm{a} & =\text { koefesien. }
\end{array}
$$

\section{Uji Hipotesis}

Uji hipotesis digunakan untuk mengetahui apaka hipotesis peneliti diterima atau ditolak. Uji hipotesis dilakukan melalui uji $\mathrm{t}$ dan uji $\mathrm{F}$. Uji t digunakan untuk mengetahui pengaruh variabel bebas terhadap variabel terikat secara parsial. Sedangkan uji F digunakan untuk melihat pengaruh secara simultan.

\section{Uji Asumsi Klasik \\ Uji Multikolinearitas}

Uji multikolinearitas dimaksud untuk melihat variabel yang digunakan dalam penelitian dalam keadaan linier sempurna. Sehingga variabel dalam penelitian tidak memiliki hubungan linier dengan variabel lainya. Uji multikolinearitas dalam penelitian ini menggunakan uji correlation matrix dengan batas nilai koefisien probabilitasnya 0,85 .

\section{Uji Heteroskedasititas}

Pengujian ini bertujuan untuk mengetahui apakah dalam model regresi terdapat masalah heteroskedasititas atau tidak. Uji heteroskedasititas dalam penelitian ini menggunakan bantuan uji Breusch-Pagan. Standar nilai Obs*R-squered dalam penelitian ini sebesar 5\%, maka dikatakan tidak terdapat masalah heteroskedasititas apabila nilainya dibawah $5 \%$.

\section{Uji Autokorelasi}

Uji autokorelasi bermaksud untuk melihat seberapa besar korelasi kesalahan antar sampel pada periode $t$ dengan kesalahan periode $\mathrm{t}-1$. Autokorelasi dalam penelitian ini dicari dengan menggunakan metode uji Lagrage Multipliner (LM).

Uji Normalitas

Uji normalitas dilakukan untuk melihat dalam model regresi bahwa variabel dalam penelitian telah terdistribusi secara normal. Variabel yang terdistribusi normal akan menghasilkan hasil yang tidak bias. Melalui uji Jarque-Berra (J-B) dengan batas nilai 10\%.

\section{HASIL PENELITIAN}

Hasil uji unit root DF-ADF didapatkan bahwa variabel nilai ekspor, tingkat inflasi dan kurs rupiah stationer belum stationer pada tingkat level. Karena belum statioenr pada tingkat level maka harus dilanjutkan pada uji derajat kointegrasi hingga didapatkan data variabel yang stationer. Uji derajat kointegrasi juga menggunakan Uji DF-ADF dengan tingkat first difference atau second difference.

Uji derajat kointegrasi didapatkan bahwa data variabel telah stationer pada tingkat first difference. Artinya variabel-variabel dalam penelitian memiliki derajat kointegrasi fist difference. Derajat kointegrasi juga digunakan sebagai batas untuk mendapatkan variabel yang berkointegrasi. Hal ini dapat dilihat dari hasil uji unit root tingkat first difference sebagai berikut:. 
Tabel 1. Hasil uji unit root tingkat first difference

\begin{tabular}{llll}
\hline Variabel & DF & ADF & Keputusan \\
\hline Kurs & -2.963972 & -4.986547 & Stationer \\
Tingkat Inflasi & -2.963972 & -4.192824 & Stationer \\
Nilai Ekspor & -2.963972 & -6.733510 & Stationer \\
\hline
\end{tabular}

Sumber : Output EViews $9 \mathrm{SV}$

Berdasarkan tabel 1. didapatkan bahwa data kurs rupiah, tingkat inflasi dan nilai ekspor telah stationer pada derajat kointergasi first diffence. Setelah data variabel stationer maka dapat dilanjutkan kedalam uji kointegrasi. Untuk melihat apakah variabel dalam penelitian memiliki hubungan atau kointegrasi dilakukan melalui uji Johansen. Hasil uji Johansen didapatkan bahwa variabel memiliki kointegrasi 1 pada nilai kritis 0,05 . Artinya bahwa variabel penelitian memiliki kointegrasi atau hubungan satu arah. Satu arah yang dimaksud adalah variabel bebas berpengaruh terhadap variabel terikat dan tidak sebaliknya. Jadi, variabel nilai eskpor dan tingkat inflasi berpengaruh terhadap kurs rupiah.

Setelah lolos uji kointegrasi maka dengan demikian variabel-variabel penelitian dapat dilanjutkan kedalam tahapan uji selanjutnya. Tahapan analisis selanjutnya adalah dengan uji ECM untuk melihat pengaruh atau tidaknya variabel nilai ekspor dan tingkat inflasi terhadap kurs rupiah tahun 2009-2016. Hasil uji ECM dapat dilihat pada tabel berikut ini:

Tabel 2. Hasil Uji ECM

\begin{tabular}{lrrrr}
\hline \multicolumn{1}{c}{ Variable } & Coefficient & Std. Error & t-Statistic & Prob. \\
\hline \hline C & 3973.728 & 3865.428 & 1.028018 & 0.3127 \\
_INFLASI & 166.5942 & 71.75960 & 2.321560 & 0.0278 \\
_EKSPOR & $-4.03 E-08$ & $2.32 \mathrm{E}-08$ & -1.738318 & 0.0931 \\
$\quad$ ECT & -244.6160 & 229.9081 & -1.063973 & 0.2964 \\
\hline \hline & & & & \\
R-squared & 0.306601 & Mean dependent var & -73.87500 \\
Adjus ted R-squared & 0.232308 & S.D. dependent var & 585.5440 \\
S.E. of regression & 513.0419 & Akaike info criterion & 15.43506 \\
Sum squared resid & 7369937. & Schwarzcriterion & 15.61828 \\
Log likelihood & -242.9610 & Hannan-Quinn criter. & 15.49579 \\
F-statistic & 4.126934 & Durbin-Watson stat & 2.297438 \\
Prob(F-s tatistic) & 0.015264 & & \\
\hline \hline
\end{tabular}

Sumber : output EViews 9,5 SV (data diolah)

Berdasarkan hasil uji ECM pada tabel 2 menunjukkan bahwa variabel nilai ekspor dan tingkat inflasi yang digunakan dalam penelitian ini berpengaruh terhadap kurs rupiah secara signifikan dibuktikan dengan probabilitas sebesar $0,015<0,05$. Hal ini ditunjukan pada nilai R-squared sebesar 0,306 atau 30,6\%, artinya variabel babas memiliki pengaruh terhadap kurs rupiah sebesar $30,6 \%$ dan sisanya dipengaruhi oleh variabel bebas diluar model.Menurut Widarjo (dalam Basuki dan Nano, 2016:220) koefisien koreksi ketidak seimbangan ECT dalam bentuk nilai absolut menjelaskan waktu yang diperlukan untuk mendapatkan nilai keseimbangan.

Hasil koefisien ECT pada tabel1. sebesar 244.6160, mempunyai makna perbedaan antar kurs dengan nilai keseimbangan sebesar 244.6160 dalam kurun waktu satu tahun. Selanjutnya untuk mengetahui hipotesis yang digunakan peneliti diterima atau tidak maka harus dilakukan uji hipotesis. Uji hipotesis melalui uji t menunjukkan bahwa variabel tingkat 
inflasi berpengaruh signifikan dengan probabilitas 0,02 $<0,05$ nilai kritisnya. Sebaliknya dengan variabel nilai ekspor yang tidak berpengaruh, karena nilai probabilitasnya 0,09> 0,05 nilai kritisnya. Hasil uji $\mathrm{F}$ menunjukkan bahwa secara simultan variabel tingkat inflasi dan nilai ekspor berpengaruh signifikan terhadap kurs rupiah.

Pengujian selanjutnya adalah uji asumsi klasik yang digunakan untuk mengetahui ada tidaknya penyimpangan asumsi klasik dari hasil penelitian dalam persamaan regresi dan ketepatan model yang digunakan. Uji multikolonieritas melalui correlation matrix didapatkan bahwa nilai korelasi seluruh variabel dalam penelitian ini kurang dari 0,8 . Sehingga dapat disimpulkan bahwa variabel dalam model tidak terdapat korelasi atau hasil penelitian terbebas dari masalah multikolonieritas.

Uji heteroskedasititas melalui uji Breusch-Pragan (white) didapatkan bahwa nilai probabilitas Chi-Square sebesar 0,51 sedikit lebih besar dari 0.5 atau standart error. Sehingga dapat disimpulkan bahwa variabel dalam model memiliki masalah heteroskedasititas, hal ini perlu diwasadai oleh peneliti. Karena ketidaksamaan varians residual dari satu pengamatan dengan penagamatan lainya. Uji autokorelasi dalam penelitian ini melalui bantuan uji serial correlation LM, uji autokorelasi digunakan untuk mengetahui kesalahan pada periode sekarang dengan perode sebelumnya. Hasil uji autokorelasi didapatkan nilai probabilitas ChiSquares sebesar 0,2<0,5, maka model terdapat masalah autokorelasi. Adanya masalah autokorelasi dapat menunjukan adanya masalah dalam stationeritas variabel dalam penelitian. Uji normalitas dengan uji Jarque-Berra (JB) digunakan untuk mengatahui apakah residual terdistribusi normal. Hasil uji JB menunjukan bahwa residual terdistribusi secara norma, hal ini ditunjukan dengan nilai probabilitas $0,8>0,5$ dan $0,8<1$.

\section{PEMBAHASAN}

\section{Pengaruh nilai ekspor terhadap kurs rupiah}

Hasil uji hipotesis melalui uji t dalam penelitian ini menyatakan bahwa nilai ekspor tidak berpengaruh terhadap kurs rupiah tahun 2009-2016 maka hipotesis ditolak. Menurut Dankiw (2004:275-276) dalam necara pembayaran tidak hanya berisi transaksi barang dan jasa saja tetapi huga penjualan aset-aset negara maupun perusahaan. Jadi nilai ekspor dapat berpengaruh ketika neraca dalam neraca pembayaran surplus. Hasil penelitian ini sesuai dengan hasil penelitian yang dilakukan oleh Hazizah, dkk (2017:10-11) bahwa ekspor tidak berpengaruh terhadap kurs karena tidak berfluktuasi selama periode penelitian. Berbeda dengan hasil penelitian Sedyaningrum dkk (2016:119) menyatakan nilai ekspor berpengaruh terhadap nilai tukar. Hubungan yang tidak signifikan ini disebabkan karena nilai eskpor cendenrung mengalami penurunan sejalan dengan kurs rupiah yang juga mengalami pelemahan.

Bagi negara dan perusahaan MNC nilai ekspor merupakan pendapatan dari perdagangan internasional yang dilakukanya. Nilai ekspor memilliki pengaruh pada pendapatan keduanya melalui neraca pembayaran. Tetapi dalam neraca pembayaran tidak hanya berisi nilai ekspor saja, didalamnya juga berisi catatan transaksi aset. Bagi peerusahaan MNC nilai ekspor yang didapatkan merupakan bagian dari aset perusahaan. Sehingga akan berpengaruh terhadap keputusan dalam mengkonversikan nilai ekspor kedalam kurs domestik atau tetap dalam valuta asing. Hal ini juga berpengaruh terhadap laba perusahaan MNC. 


\section{Pengaruh tingkat inflasi terhadap kurs rupiah}

Berdasarkan hasil uji t maka hipotesis yang menyatakan bahwa terdapat pengaruh signifikan antara tingkat inflasi terhadap kurs rupiah tahun 2009-2016 diterima. Menurut Sukirno (2012:402) tingkat inflasi yang berlaku pada umumnya cenderung menurunkan nilai suatu valuta asing. Hal ini sesuai dengan hukum paritas daya beli atau teori PPP. Meningkatnya harga barang atau jasa akan berdampak pada peningkatan permintaan valuta asing. Sejalan dengan hasil penelitian yang menyatakan bahwa tingkat inflasi berpengaruh terhadap kurs rupiah tahun 2009-2016. Hasil penelitian ini juga sesuai dengan hasil penelitian yang dilakukan oleh Haryadi (2014:16). Berbeda dengan hasil penelitian Syahtria, dkk (2016:65) yang menyatakan bahwa inflasi tidak berpengaruh terhadap kurs rupiah. Perbedaan hasil penelitian tersebut dapat terjadi karena lama waktu yang digunakan dalam penelitian juga berbeda-beda.

Tingkat inflasi atau kenaikan harga juga berdampak pada kenaikan pendapatan perusahaan MNC. Tingkat inflasi yang berpengaruh terhadap kurs rupiah menjadikan perusahaan MNC tidak merasakan dampak dari kenaikan tingkat inflasi. Pendapatan yang meningkat dan kurs rupiah yang melemah tidak berdampak signifikan bagi perusahaan MNC ketika pendapatanya dikonversikan kedalam valuta asing. Hal ini terjadi karena kurs rupiah yang mengalami pelemahan atau depresiasi. Hasil penelitian Andes, dkk (2017:1) menyatakan bahwa kurs rupiah berpengaruh terhadap return saham perusahaan. Maka perusahaan MNC perlu memperhatikan tingkat inflasi sehingga dapat menjaga perusahaan supaya tidak rugi dan menjamin investor dalam pembagian retun saham.

\section{KESIMPULAN}

Berdasarkan hasil analisis data dengan menggunakan regresi metode koreksi kesalahan atau lebih dikenal dengan sebutan ECM (Error Correction Model) pada penelitian pengaruh nilai ekspor dan tingkat inflasi terhadap kurs rupiah tahun 2009-2016, maka diperoleh kesimpulan bahwa tingkat inflasi berpengaruh signifikan terhadap kurs rupiah tahun 20092016 dan nilai ekspor tidak berpengaruh terhadap kurs rupiah tahun 2009-2016 secara parsial. Hasil uji secara simultan menunjukan bahwa nilai ekspor dan tingkat inflasi berpengaruh signifikan terhadap kurs rupiah tahun 2009-2016. Penelitian ini hanya menggunakan dua variabel makro ekonomi saja.

\section{SARAN}

Bagi peneliti selanjutnya disarankan untuk menambahkan variabel makro ekonomi seperti impor, tingkat suku bunga dan pendapatan negara serta menambah lama waktu penelitian.

\section{DAFTAR PUSTAKA}

Andes, S.L., Puspitaningtyas, Z dan Prakoso, A. 2017. Pengaruh Inflasi, Kurs Rupiah dan Suku Bunga terhadap Returs Saham Perusahaan Manufaktur. Jurnal Akuntansi. Vol. 10, No. 2, pp.8-16.

Basuki, A. T dan Nano P., 2016. Analisis Regresi dalam Penelitian Ekonomi dan Bisnis (dilengkapi Aplikasi SPP dan EViews).1 ed. Jakarta: PT Raja Grafindo Persada.

Fatmawati, S dan Astuti, P., 2013. Dasar-Dasar Ekspor Impor Teori, Praktek dan Prosedur. 1 ed. Yogyakarta: UPP STIM YKPN. 
Haryadi, 2014. Pengaruh Inflasi Suku Bunga Jumlah Uang Beredar dan Pendapatan Nasional Terhadap Nilai Tukar Rupiah per US Dollar. Jurnal Paradigma Ekonomika, Vol. 9, No. 01 (21), pp. 1-21.

Hazizah, N., Zainuri., dan Sebastian V, 2017. Pengaruh JUB, Suku Bunga, Inflasi, Ekspor dan Impor terhadap Nilai Tukar. Karya IImiah Civitas Akademika Program Studi Ekonomi Pembangunan, Volume IV (1) (7), pp. 97-103.

Sedyaningrum, M., Suhadak dan Nila F. N, 2016. Pengaruh Jumlah Nilai Ekspor, Impor dan Daya Beli Masyarakat di Indonesia. Jurnal Administrasi Bisnis (JAB), Vol. 34 No. 1 (8), pp. 141-148.

Sukirno, S., 2012. Makroekonomi Teori Pengantar. Jakarta: PT Raja Grafindo Persada.

Syahtria, M.F, Suhadak dan Nila, F, 2016. Dampak Inflasi, Fluktuasi Harga Minyak dan Emas Dunia terhadap Nilai Tukar Rupiah dan Pertumbuhan Ekonomi. Jurnal Administrasi Bisnis (JAB), Vol. 32 No. 2|(10), pp. 59-68. 